\title{
STIMULASI KREATIFITAS ANAK USIA DINI DENGAN MENGGUNAKAN MENARA KUBUS
}

\author{
Siswi Wulandari \\ Universitas Kadiri \\ wulandarisiswi@gmail.com
}

\begin{abstract}
This community service activity is an implementation activity from the results of previous research. This activity aims to stimulate the creativity of early childhood. The method used is lectures, and practice constructing buildings / towers from cubes / blocks. The results of this activity are very useful for early childhood and the children's enthusiasm is seen when the children tell the cubes / blocks that the parents have arranged.
\end{abstract}

Keywords: Creativity; Cube tower; early childhood

\begin{abstract}
Abstrak
Kegiatan pengabdian masyarakat ini merupakan kegiatan implementasi dari hasil penelitian sebelumnya. Kegiatan ini bertujuan untuk menstimulus kreatifitas anak usia dini. Metode yang digunakan ceramah, dan mempraktekan menyusun bangunan/Menara dari kubus/balok. Hasil dari kegiatan ini sangat bermanfaat untuk anak usia dini dan antusias anak terlihat saat anak menceritakan kubus/balok yang disusun kepada orang tua.
\end{abstract}

Kata Kunci: kreatifitas; menara kubus; anak usia dini

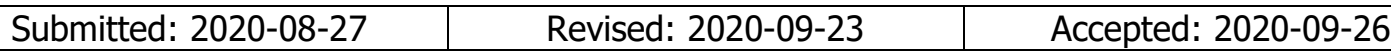

\section{Pendahuluan}

Kelompok bermain adalah wadah pembinaan sebagai usaha kesejahteraan anak dengan menggunakan kegiatan bemain dan menyelenggarakan pendidikan para sekolah bagi anak yang berusia sekurang-kurangnya 3 tahun sampai memasuki pendidikan dasar. Pendidikan anak usia dini khususnya pada jenjang kelompok bemain dalam menyelenggarakan pendidikan menfokuskan pada peletakan dasar kearah penumbuhan dan perkembangan semua aspek.

Idealnya keberadaan kelompok bermain (KB) sangat diperlukan sebagai usaha membantu meletakkan dasar pengembangan multi potensi dan multi kecerdasan pada diri setiap anak berupa pengetahuan, keterampilan dan sikap sebelum anak memasuki jenjang pendidikan selanjutnya. Selain itu, adanya kelompok bermain juga merupakan fenomena kehidupan masyarakat yang memberikan layanan pendidikan anak usia dini sebagai suatu kebutuhan masyarakat modern.

Salah satu jenis permainan yang bisa meningkatkan semua aspek perkembangan anak adalah bermain balok (Wulandari et. all). Dengan bermain balok dapat membentuk anak-anak menjadi pembangun aktif sesuai pikiran mereka tentang bangunan. Karena dalam pennainan balok ini melibatkan fisik, social dan intelektual anak. Sehingga dapat menunjang pertumbuhan anak secara maksimal. 


\section{Metode}

Penelitian ini menggunakan metode interpretatif yaitu menginterpretasikan data mengenai fenomena / gejala yang diteliti di lapangan. Langkah dalam pengabdian masyarakat ini adlaah sebagai berikut:

1. Survey Lokasi Pengabdian Masyarakat

Pemilihan lokasi ditentukan berdasarkan pada kepentingan actual. Sebelum menentukan lokasi kegiatan terlebih dulu dilakukan survey dan menanyakan prosedur penguruan ijin ditempat tersebut.

2. Instrumen yang digunakan
a. Alat Permainan Edukasi (APE)
b. Leaflet
c. Ballpoint
d. Instrumen penilaian berdasar hasil penelitian sebelumnya
e. Lembar peniliaian KPSP
f. Absensi Kehadiran

3. Jadwal Kegiatan

\begin{tabular}{ccccc}
\hline No. & $\begin{array}{c}\text { Uraian } \\
\text { Kegiatan }\end{array}$ & Agustus & September & Oktober \\
\hline 1 & $\begin{array}{l}\text { Pengurusan } \\
\text { Perijinan }\end{array}$ & $\mathrm{X}$ & & \\
2 & $\begin{array}{l}\text { Persiapan } \\
\text { pelaksanaan }\end{array}$ & $\mathrm{X}$ & & \\
3 & $\begin{array}{l}\text { Pelaksanaan } \\
\text { Kegiatan } \\
\text { Pembuatan }\end{array}$ & & $\mathrm{X}$ & \\
& Laporan & & $\mathrm{X}$ \\
\hline
\end{tabular}

4. Observasi

a. Model pembelajaran kelompok

b. Kegiatan dilakukan anak sambal belajar dalam kelompok

c. Pengaturan kelas anak membentuk lingkaran dan pendidik duduk bersama anak-anak

d. APE yang digunakan disesuaikan dengan kebutuhan

5. Wawancara dengan guru

a. Pemggunaan model belajar kelompok

b. Kegiatan yang dilakukan dalam bermain balok anak dibiarkan dengan kreasinya membuat bentuk-bentuk bangunan sesuai imajinasinya

c. Pendidikan memberikan arahan penjelasan lalu meminta anak untuk melaksanakan kegiatan

d. APE alat utama dalam pembelajaran harus disesuaikan dengan kebutuhan

e. Anak-anak duduk melingkar, guru ditengah-tengah anak-anak

f. Orang tua/wali murid sangat berperan dalam KB Nidzammiyah Kec. Mojoroto, Kota Kediri 
6. Dokumentasi

mengumpulkan bukti-bukti itu dan penelasan yang lebih luas mengenai fokus penelitian

\section{Hasil dan Pembahasan}

Kegiatan Pengabdian Masyarakat ini dilakukan pada bulan September 27-28 September 2019 bertempat di KB Nidzammiyah Kec. Mojoroto Kota Kediri pukul $08.00-$ 10.00 WIB. Jumlah peserta dalam kegiatan pengabdian masyarakat adalah sebanyak 23 siswa, mulai dari awal kegiatan sampai akhir kegiatan tidak ada yang meninggalkan kelas. Pada awal kegiatan siswa belum bisa membedakan balok kubus dengan bentuk yang lain. Peserta (siswa, guru dan orang tua) mengatakan kegiatan ini sangat bermanfaat untuk menambah pengetahuan dan perkembangan siswa. Pada permainan Menara kubus yang dikerjkaan tanpa paksaan orangtua atau ditemani orang tua akan merangsang perkembangan karena anak membuat dan membereskan mainan (Menara kubus). Semakin sering dilakukan latihan, anakakan semakin terampil, karena permainan ini termasuk Skill Play. Gerak yang melibatkan bagian-bagian tubuh tertentu dan dilakukan oleh otot-otot kecil tetapi memerlukan koordinasi yang cermat.

Periode terpenting untuk masa pertumbuhan dan perkembangan adalah pada masa balita. Masa ini berlangsung sangat cepat dan tidak terulangsehingga disebut dengan golden age atau masa keemasan. Kegiatan yang mampu mnumbuhkan kreatifitas adalah bermain. Bermain merupakan kebutuhan anak sesuai dengan tahap perkembangan, status kesehatan anak, lingkungan dan permainan yang cocok.

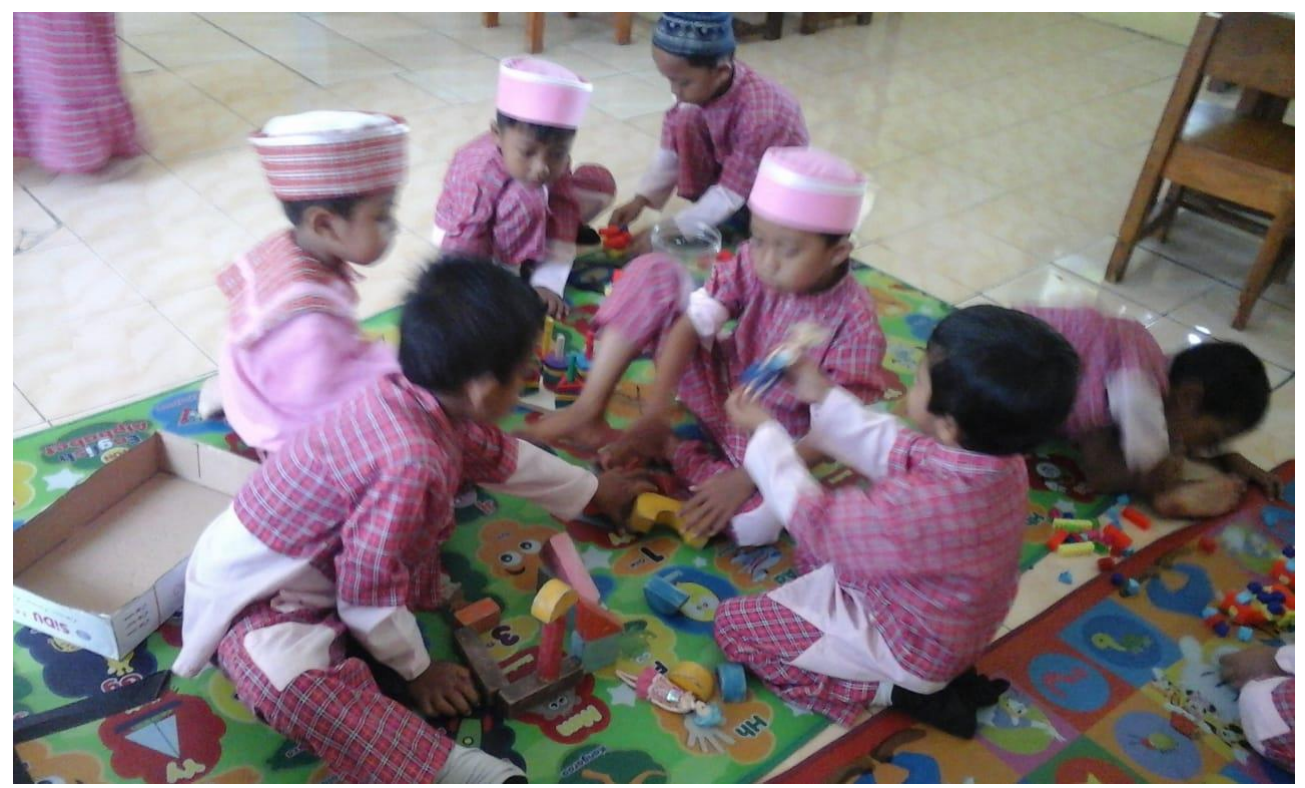

Gambar 1. Siswa mempraktekan membuat bangunan dengan menggunakan balok/kubus

Siswa sedang membentuk bangunan dengan menggunakan kubus/balok. Setelah terbentuk bangunan/Menara sesuai dengan imajinasi, siswa menunjukan ke orangtua/wali murid dan mencerikan bangunan yang dibuat. Siswa pada awalnya masih belum bisa membedakan antar bentuk/bangunan. 


\section{Kesimpulan}

Kegiatan pengabdian masyarakat ini terlaksana dengan baik dan lancer sesuai tujuan dari pengabdian masyarakat ini, semua peserta yang hadir mampu mempraktekan membentuk menara/bangunan menggunakan balok/kubus sesuai imajinasi di KB Nidzammiah Kec.Mojoroto Kota Kediri. Antusias peserta sangat terlihat saat siswa mulai membuat bangun dan menunjukan pada orang tua. Selain menunjukan bentuk bangunan/menara, siswa juga menceritakan hasil karyanya, hal ini menunjukan siswa telah sesuai dengan instrument penilaian perkembangan (KPSP).

\section{Daftar Pustaka}

Asmawati, Luluk and Novita, Dian and Amini, Mukti and Pujiastuti, Sri Indah (2014) Pengelolaan Kegiatan Pengembangan Anak Usia Dini. In: Ruang Lingkup Pengelolaan Kegiatan di Lembaga PAUD. Universitas Terbuka, Jakarta, pp. 1-55. ISBN 9789790112933

Gunarti, Winda and Muis, Azizah (2014) Metode Pengembangan Perilaku dan Kemampuan Dasar AUD. In: Hakikat Perilaku dan Kemampuan Dasar Anak Usia 3-4 Tahun. Universitas Terbuka, Jakarta, pp. 1-51. ISBN 9790112351

Kemalawati, I. (2017). Upaya Meningkatkan Kreativitas Anak Melalui Alat Permainan Balok di Taman Kanak-Kanak Cipta Mulia Kecamatan Cipatat Kabupaten Bandung Barat. EMPOWERMENT: Jurnal IImiah Program Studi Pendidikan Luar Sekolah, 6(1).

Kusumaningtyas, L. E. (2016). Bermain dalam Rangka Mengembangkan Motorik pada Anak Usia Dini. JURNAL INDRIA (Jurnal IImiah Pendidikan Prasekolah dan Sekolah Awal), 1(1).

Nurhastuti, E. (2014). PENGEMBANGAN KREATIVITAS MELALUI BERMAIN BALOK PADA ANAK KELOMPOK B TK TANGGAN I KECAMATAN GESI KABUPATEN SRAGEN TAHUN AJARAN 2014/2015 (Doctoral dissertation, Universitas Muhammadiyah Surakarta).

Prabekti, N. (2011). Peranan alat permainan edukatif dalam mengembangkan kemampuan motorik anak usia dini di PAUD Narusysyamsi Tanggung Turen Malang (Doctoral dissertation, Universitas Negeri Malang).

Rahardjo, B. (2007). Aplikasi teori bermain untuk anak usia sekolah. Jurnal Didaktika, 8(3), 260-270.

Sari, H. P., \& Ediatmi, E. (2017). Pengaruh Permainan Menara Kubus Terhadap Perkembangan Balita Umur 14-18 bulan Di Posyandu Wilayah Puskesmas Pesantren II Kota Kediri Tahun 2015. Jurnal Kebidanan Midwiferia, 2(1), 1-10.

Sit, M. (2017). Psikologi Perkembangan Anak Usia Dini Edisi Pertama. Kencana.

Suryana, D. (2014). Kurikulum Pendidikan Anak Usia Dini Berbasis Perkembangan Anak. Jurnal Pesona: Jurnal Pendidikan Dasar Dan Humaniora, 2(1), 65-72.

Wijana, Widarmi D. and Suminah, Enah and Nurmiati, and Siyantayani, Yulianti (2014) Kurikulum PAUD. In: Konsep Dasar Pendidikan Anak Usia Dini. Universitas Terbuka, Jakarta, pp. 1-40. ISBN 9789790113084

Wulandari, S., \& Aprilia, L. (2016). Hubungan Antara Bermain Aktif Dengan Perkembangan Sosial Pada Anak Pra-Sekolah Usia 4-6 Tahun Di Tk Dharma Wanita Persatuan Boro. Java Health Jounal, 3(2), 80-80. 
BERNAS:

Jurnal Pengabdian Kepada Masyarakat

Vol.1 No. 4, October 2020, pp. 449-453

453

Yus, A. (2011). Model pendidikan anak usia dini. Kencana. 